\title{
Gestalt contact styles in OCD patients: a controlled study
}

\author{
HÜSEYIN ÜNÜBOL ${ }^{1}$ \\ https://orcid.org/0000-0003-4404-6062 \\ Meltem TopaloĞLU1 \\ https://orcid.org/0000-0002-6998-4429
}

Received: $12 / 17 / 2018$ - Accepted: 11/05/2019

DOl: 10.1590/0101-60830000000221

1 Psychology, Uskudar University, Istanbul, Turkey.

\begin{abstract}
Background: Obsessive-compulsive disorder is a challenging disease in terms of remission rates and treatment approaches. All theoretical approaches are needed for a better understanding. Compared to other theories, it has not been examined sufficiently from the perspective of gestalt theory in the literature. Objective: To examine and compare the Gestalt Contact Styles of patients with obsessive-compulsive disorder (OCD) and the Control Group and to examine the relationship between Gestalt Contact Styles and OCD symptoms. Methods: 50 OCD patients were compared with the healthy control group. All patients were evaluated with the Yale Brown Obsessive-Compulsive Scale (Y-BOCS), the Padua Inventory (PI), and the Gestalt Contact Styles Scale-Revised Form (GCSS-RF). For the control group, GCSS-RF was applied. Results: The scores of the OCD patients for GCSS-RF "Retroflection" and "Deflection" subscales were significantly higher than the Control Group. Statistically significant high scores were found between the subscales of Padua Inventory "contamination obsessions and washing compulsions", "obsessional thoughts", "obsessional impulses" and "checking compulsions" subtypes and Gestalt contact styles in the Patient Group in a symptomatological examined manner. With these findings, in terms of Gestalt Contact Styles, it is seen that the difference between Patient and Control Groups is significantly different. There was no significant relationship between the Yale-Brown total score of the Patient Group and the GCSS-RF subscales. Discussion: In conclusion, the findings of the study showed significant differences in terms of Gestalt Contact Styles (Retroflection, Contact, Deflection, Desensitization, Confluence) in Patient and Control Groups and OCD symptoms. These results are important to Gestalt Therapists in terms of shedding light on the therapeutic intervention to be done for an OCD patient and contributing to the literature.
\end{abstract}

Ünübol H, Topaloğlu M / Arch Clin Psychiatry. 2020;47(1):1-6

Keywords: Obsessive-compulsive disorder, gestalt theory, contact styles.

\section{Introduction}

Obsessive-compulsive disorder (OCD) is a mental health disorder that causes low social and occupational functioning in addition to low quality of life ${ }^{1,2}$. OCD is characterized by two main symptoms: obsessions and compulsions. Obsessions are persisting, intrusive thoughts or images 3 leading to lasting worries and compulsions that are repetitive compensatory behaviors to reduce obsessions-related anxiety. In Salkovskis ${ }^{4}$ (1985), Beck's (1976) cognitive OCD theory of cognitive anxiety theory argues that the main problem of OCD is not their own ideas (ie, obsessions). Those who are OCD are more negative and more conscious of this belief in obsession than what is seen in other people 4 . Cognitive behavior therapy (CBT) and exposure-based interventions are first-line psychological treatments for OCD, but only $50 \%$ of people benefit from treatment when considering treatment rejection and quitting rates ${ }^{5-7}$. For the last two decades, special efforts have been made to clarify the nature and content of the assessment of obsessions, but nevertheless have not resulted in any improvement in treatment. Most treatments for OCD currently focus on symptom reduction (ie, exposure and response prevention $)^{8}$. However, interpersonal difficulties in the treatment of OCD are also subject to special attention ${ }^{9}$. Previous research has shown that factors such as low self-esteem, avoidance of activities and people, lack of closeness in relationships and fear of rejection by others in OCD patients are causing an increase in obsessions and compulsions ${ }^{10}$.

Historically, other factors linked to OCD have been guilt or moral sensitivity issues ${ }^{11}$ and have begun to be re-examined as potentially critical factors in continuation of obsessions over time ${ }^{12}$. The role of moral emotions in OCD, especially because of guilt or failure, has long taken a place in OCD phenomenology11,13-15. Mancini et al. (2004) have shown that raising a sense of guilt and a high sense of responsibility brings more control and more hesitation (ie, obsessive- compulsive tendencies) in a task, more than just individuals who have a high sense of responsibility ${ }^{16}$.

Doron and his colleagues point out that OCD individuals have a domain of self-concept in which morality is highly valued, but they feel inadequate ${ }^{17}$. Zhong and Liljenquist (2006) observed that threats to their moral competence in healthy individuals increased their desire to clean themselves ${ }^{18}$ (e.g. antiseptic wipes); This has significantly reduced negative moral sentiments (e.g. guilt, regret, etc.) and increased other compensatory behaviors (e.g. voluntary restoration of moral self-esteem to help another work) ${ }^{19}$.

The literature also shows that another moral emotion, shame, plays an active role in OCD individuals. It shows that both the shame sensitivity and the changes in shame are related to changes in the severity of symptoms ${ }^{20}$. Most of those with OCD approve rituals of hiding from others ${ }^{21}$. Given the role of thought-action fusion in OCD, it is not hard to imagine that fears of accidental harm to others, pollution of others, or unacceptable thoughts (in other words, sinners, deliberate harm to others, sexual deviance) can cause humiliation.

Shame is a feeling that reflects self-evaluation, such as guilt; such emotions cause not just behavior, but the entire self as negative ${ }^{22}$. For this reason, these emotions tend to be excluded from the field of awareness. Different therapeutic approaches deal with the concept of awareness. Cognitive behavioral therapies have enriched themselves by adding the concept of awareness to their theories, while the Gestalt approach considers that consciousness is the main goal of therapy. The eastern meditation advocates that by using the generic awareness as a base, the individual can focus on the following events by accepting the opinions and feelings of himself and others ${ }^{23}$. Increasing interest in the concept of awareness has led to an increase in the importance of the "now and here" approach. The "now-and-here" approach underlying the base methodology of the existentialist approach is one of the most common concepts 
adopted by humanist-existentialist approaches. Lately, like cognitive behavioral therapy, many therapies have begun to incorporate the "now-and-here" approach into their theories.

The Gestalt approach is an approach under the umbrella of humanist approaches. It was developed in the 1940's by Fritz Perls, Laura Perls and Paul Goodman ${ }^{24}$. Considering the basis on which the Gestalt therapy approach is based, it can be understood that it is shaped by various theories and opinions such as humanist approach, existential approach, phenomenological approach, holistic view, field theory and Far Eastern philosophy. Gestalt therapy focuses on the present time and adopts the now and now approach. On the other hand, the basic concepts addressed by Gestalt application are concepts such as awareness, communication, forms of communication, personal responsibility ${ }^{25}$. Awareness is a form of experience that is defined as the relationship between the present reality and the individual's own being ${ }^{26-28}$. Awareness involves the accumulation of knowledge about communicating with other people, responsibility for election, self-acceptance, insight, and preconscious ${ }^{25}$.

Another strength of Gestalt is a new and deeper understanding of what we mean by support in a relational domain model. In earlier Gestalt's individual self-model, embarrassment was understood more simply as a sense of inferiority ${ }^{29}$. The approach to work with emotional dynamics later claimed that instead of disgracing, assessed shame as the adaptation to social life and claimed that an empathic dialogue could grow $^{29}$. For this reason, empathic understanding through dialogue is seen as an important part of the change process. Investigating the feelings of guilt and embarrassment and determining how the client keeps the obstacles that prevent the client from resolving this conflict is one of the basic goals of the therapeutic approach. Gestalt therapy does not categorize clients according to DSM- 5 criteria. Although incompatible with a particular diagnostic context, Gestalt therapy can be adapted to the therapist's ability to work with various disorders ${ }^{30}$. Seligman and Reichenberg (2015) stated that gestalt therapy can be successfully used with the following disorders: emotional disturbances, anxiety disorders, somatoform disorders, artificial disorders, adjustment disorders and some personality disorders or personality traits (evasive, addictive, narcissistic, histrionic and obsessive compulsive disorders) ${ }^{31}$. While observing various case studies and literature reviews, it is clear that Gestalt therapy may be useful with a wide range of mental health problems, including, but not limited to, depression ${ }^{32}$, post-trauma, bipolar disorder ${ }^{30}$, borderline personality disorder and self-harm ${ }^{33}$ ), stress disorder, substance abuse, anxiety ${ }^{34}$, bulimia nervosa ${ }^{35}$, schizophrenia $^{36}$ and dementia ${ }^{37}$.

Other important concepts in the Gestalt approach are communication and communication styles. These concepts explain how individuals communicate and how they adapt to or differ from their needs and environments. Communication is seen as a source of life for growth. It is also necessary for survival and change $e^{38,39}$ because the individual exists as part of a particular circle. According to the Gestalt approach, communication means contacting the self and the environment without losing their personality ${ }^{27}$. In fact, all people interact with each other. Nevertheless, it is important to be conscious of how contact is maintained in the process of contact (accommodation variance). How to contact is about communication styles. In line with the principles of the Gestalt approach, there are basically six contact styles: retroflection, desensitization, confluence, projection, deflection, and introjection. It is necessary to raise awareness in order to be able to realize the communication styles. It is also important to raise awareness about communication styles because it helps the individual to understand their resistance and unfinished businesses. Contact is an inevitable part of change and growth ${ }^{25}$.

\section{Methods}

\section{Participants}

This study's universe consisted of voluntary patients, who had obsessive-compulsive disorder at the ages of 18-65 who were treated remotely at the NP Feneryolu Medical Center $(\mathrm{N}=32)$ and Erenköy Mental and Neurological Disorders Training and Research Hospital $(\mathrm{N}=18)$. A group of 50 patients were targeted. Sixty-five patients were interviewed by psychiatrists working in the hospital who made their diagnoses and guiding. It was composed of patients who had been followed up with OCD diagnosis for more than 1 year and had not received any psychotherapy treatment other than drug treatment. 5 people stated that they did not want to be included in the study and 10 people were not included in the study because of the additional diseases such as depression and social phobia which were also confirmed during the interview. After reaching 50 people, relatives of patients with similar socio-cultural characteristics and no active psychiatric illness were tried to reach 50 healthy volunteers who were included in the control group of the hospital staff. Especially gender and age ranges are considered. A total of 100 patients were enrolled in the study, 50 patients ( 28 female, 22 male, $\mathrm{N}=50$ ) with OCD and 50 healthy volunteers ( 29 female, 20 male, 1 unspecified, $N=50$ ). Üsküdar University Ethics Committee of Non-Invasive Researches approved the study (No: B.08.6.YÖK.2. ÜS.0.05.0.06/2017/140, Date 05.06.2017).

\section{Measures}

\section{Yale-Brown Obsessional Compulsion Rating Scale (Y-BOCS)}

In 1989, it was developed by Goodman, Price and Rasmussen to measure the type and total severity of Obsessive-Compulsive symptoms ${ }^{40,41}$. The scale is prepared for semi-structured interviews. The scale consists of 19 items and the evaluation is made by the clinician. Each question score ranges from 0-4. Only the first 10 items (except items $1 \mathrm{~b}$ and $6 \mathrm{~b}$ ) are used to obtain the total score. Obsessions (1-5), compulsions (6-10) subscores and OCD total scores (1-10) are scored separately and the highest score is 40 . The Y-BOCS total score is the sum of these top ten items. The Turkish validity and reliability study of the scale was conducted by Karamustafalığlu et al. in 199342. The Cronbach alpha coefficient of the scale was found to be 0.81 .

\section{Padua Inventory (PI)}

Padua Inventory is a measure of the severity of the disease and the determination of the predominant symptom distribution in patients with obsessive-compulsive disorder. In addition, it allows the determination of individual severity of differentiated symptoms. Beşiroğlu et al. performed the validity and reliability studies of the Padua Inventory together with the original 60 questions ${ }^{43}$ and the 41-question forms ${ }^{44}$ adapted in 1992 . The reliability of this inventory, which was adapted to Turkish in 2005 , is $95^{45}$. The Padua inventory has five subscales: Contamination Obsessions, Obsessive Thoughts, Obsessional Impulses, Checking and Preciseness. Each item is scored between 0-4 according to the response style. The score ' 0 ' in the test items corresponds to the absence of any indication or disturbance of the depicted statement, and the score of ' 4 ' corresponds to the experience of being overly disturbed or annoying. The total score reflects the level of discomfort arising from all obsessive-compulsive symptoms, it comprises from total score belonging to each subscale and sum of all subscales.

\section{Gestalt Contact Styles Scale-Revised Form (GCSS-RF)}

Experimental examination of the contact styles of Gestalt was first carried out by Byrness in 1975. Kepner (1982) developed the Gestalt Contact Styles Scale (GCSS) from the work of Byrness. In 1986, Woldt and Kepner created a 100-item Likert-type Gestalt Contact Styles Scale Revised Form Scale by adding 24 items and increasing the quality of the scale that Kepner developed.

According to the Gestalt theory, the scale that was developed to measure the dominant forms of contact, which is of great importance 
in terms of the ways to be followed in diagnosis and therapy, was made usable in our country in 2002 by Aktaş and Daş ${ }^{46}$. As a result of the validity and reliability study, the GCSS-RF 5 factors were separated from 100 items to 61 items (contact, confluence, deflection, retroflection, emotional desensitization). For the 5 factors, the Cronbach Alpha validity coefficient of the scale was changed between 53 and 84 . The options of this scale, which are between 1 and 5 Likert types, are "very suitable for me", "suitable for me", "undecided", "not suitable for me" and "not for me at all". Separate scores are reached for each sub-dimension, and high scores indicate that related styles of contact are more dominant.

\section{Work design}

The analysis of the data was made with the SPSS 23 program and worked with a $95 \%$ confidence level. In the analysis, parametric tests (Independent Groups T Test, One-Way ANOVA) and nonparametric tests (Mann Whitney, Kruskal Wallis) were used, provided that both groups provided the assumption of normal distribution. Participants' variance according to demographic variables of Padua Inventory and sub-dimensions and Returning Points According were analyzed with Mann Whitney and Kruskal Wallis tests and ANOVA and t-tests were used to analyze the Deflection, Contact, Confluence and Emotional Desensitization scores according to differences in demographic variables. In addition, a Correlation Test was applied to determine the direction and strength of the linear relationship between the variables.

\section{Results}

Table 1 shows the distribution of patients and control groups according to their demographic characteristics. Among the participants who were sick, the rate of those 25 years and under was $32.0 \%$; The proportion of those between the ages of $26-34$ is $46.0 \%$; The proportion of those aged 35 and over is $22.0 \%$; The proportion of women was $56.0 \%$ while the proportion of men was $44.0 \%$; The proportion of married persons was $43.5 \%$ while the proportion of single persons was $56.5 \%$; The proportion of primary school graduates was $4,0 \%$; The proportion of those with a secondary school diploma was $12,0 \%$; The proportion of those who have graduated from high school was $40,0 \%$; The proportion of those who have a bachelor's degree was $40,0 \%$; The proportion of master degree holders was $4,0 \%$; The proportion of those with a poor economic status was
$4.0 \%$; The proportion of those with middle-class economic status was $86.0 \%$; The proportion of those with upper class economic status was $10.0 \%$; The proportion of current employees is $42.0 \%$.

In the control group, The rate of those 25 years and under was $26.5 \%$; The proportion of those between the ages of $26-34$ was $44,9 \%$; The proportion of those aged 35 and over was $28.6 \%$; The proportion of women was $59.2 \%$ while the proportion of men was $40.8 \%$; The proportion of married persons was $47.9 \%$ while the proportion of single persons was $52.1 \%$; The proportion of those who have graduated from secondary school was $4.1 \%$; The proportion of those who have graduated from high school was $24.5 \%$; The proportion of those with a bachelor's degree was $55.1 \%$; The proportion of master degree holders was $16,3 \%$; The proportion of those with middle-class economic status was $89,8 \%$; The proportion of those with upper-class economic status was $10.2 \%$.

Table 2 shows the findings of the Shapiro-Wilk normality analysis in order to examine the normality of the scores. According to the Shapiro-Wilk normality analysis conducted to examine the normality of the scores, Padua Inventory, and its subscales and return scores were not normally distributed $(\mathrm{p}<0,05)$; Deflection, Contact, Confluence, and Emotional Desensitization scores were normally distributed $(\mathrm{p}>0,05)$.

In Table 3, Patient and Control Group scores of GCSS-RF Deflection, Contact, Confluence, and Emotional Desensitization subscales, t-test results were compared. Since the GCSS-RF Retroflection scores were not normally distributed, the rank averages and the Mann-Whitney analysis were compared (Table 4).

There was a statistically significant difference in Retroflection points between Patient and Control Groups, which was much higher in the patient group than in the rank average group $(\mathrm{p}<$ 0.001) (Table 4).

There was statistically significant difference between Patient and Control Groups in terms of Deflection score $(p<0,001)$, Contact score $(\mathrm{p}<0,001)$ and Emotional Desensitization score $(\mathrm{p}<0,01)$. When looked into average scores, while Deflection score is greater in the patient group, Emotional Desensitization and Contact dimension scores are greater in the control group. There was no statistically significant difference between the Patient and Control Groups in terms of the Confluence sub-dimension ( $\mathrm{p}>0.05$ ) (Table 3 ).

Table 5 contains the Correlation Test findings for the scores the Patient Group received from the scales. There was no significant relationship between the Y-BOCS score and Gestalt Contact Styles

Table 1. Patient and control group distributions by demographic characteristics

\begin{tabular}{|c|c|c|c|c|c|}
\hline & & \multicolumn{2}{|c|}{ Patient } & \multicolumn{2}{|c|}{ Control } \\
\hline & & $\mathrm{n}$ & $\%$ & $\mathrm{n}$ & $\%$ \\
\hline \multirow[t]{3}{*}{ Age } & 25 age and below & 16 & 32,0 & 13 & 26,5 \\
\hline & 26-34 ages & 23 & 46,0 & 22 & 44,9 \\
\hline & 35 age and above & 11 & 22,0 & 14 & 28,6 \\
\hline \multirow[t]{2}{*}{ Gender } & Female & 28 & 56,0 & 29 & 59,2 \\
\hline & Male & 22 & 44,0 & 20 & 40,8 \\
\hline \multirow[t]{2}{*}{ Marital Status } & Maried & 20 & 43,5 & 23 & 47,9 \\
\hline & Single & 26 & 56,5 & 25 & 52,1 \\
\hline \multirow[t]{6}{*}{ Education Status } & Primary School & 2 & 4,0 & 0 & 0,0 \\
\hline & Secondary School & 6 & 12,0 & 2 & 4,1 \\
\hline & High School & 20 & 40,0 & 12 & 24,5 \\
\hline & Undergraduate & 20 & 40,0 & 27 & 55,1 \\
\hline & Graduate & 2 & 4,0 & 8 & 16,3 \\
\hline & Postgraduate & 0 & 0,0 & 0 & 0,0 \\
\hline \multirow{3}{*}{$\begin{array}{l}\text { Socioeconomic } \\
\text { Status }\end{array}$} & Low & 2 & 4,0 & 0 & 0,0 \\
\hline & Middle & 43 & 86,0 & 44 & 89,8 \\
\hline & High & 5 & 10,0 & 5 & 10,2 \\
\hline \multirow{2}{*}{$\begin{array}{l}\text { Are you working } \\
\text { now? }\end{array}$} & Yes & 21 & 42,0 & 38 & 77,6 \\
\hline & No & 29 & 58,0 & 11 & 22,4 \\
\hline
\end{tabular}


in the Patient Group ( $\mathrm{p}>0.05)$. A strong positive relationship was found between the Obsessive Thoughts subscale and the Retroflection subscale $(r=0,505 ; \mathrm{p}<0,001)$, a strongly positive relationship between the Obsessive Thoughts subscale and the Deflection subscale $(\mathrm{r}=0,556 ; \mathrm{p}<0,001)$, and there is a positive moderate correlation between the Obsessive Thoughts subscale and Confluence subdimension $(r=0.304, p<0.05)$. There was a negative correlation between Contamination Obsession subscale and Deflection score $(\mathrm{r}=-0,329 ; \mathrm{p}<0,05)$. There is a positive moderate relationship $(\mathrm{r}=$ $0.344, \mathrm{p}<0.05)$ between the Checking subscale and the Return score. There is a positive positive correlation between Checking score and Deflection sub-dimension $(\mathrm{r}=0.447, \mathrm{p}<0.01)$. Of the Patient Group there was a strong positive correlation $(r=0,283, p<0,05)$ between the Obsessional Impulses and Retroflection subdimension, there was a moderate positive correlation $(r=0,403$; $p<0,01)$ between the Obsessional Impulses subdimension and the Deflection score. There is a positive weak correlation between the Padua Inventory and the Retroflection sub-dimension, a weak positive relationship between the Deflection sub-dimension and a weak positive relationship between the Confluence sub-dimension (Table 5).

\section{Discussion}

Our study looked at the differences between OCD and Gestalt contact styles in the healthy population and with the symptoms of OCD patients. According to our results, there was a significant difference between gestalt contact styles in OCD patients and control group. In particular, the "Retroflection" contact style is considerably higher than the control group. This style of contact is a style of contact that the person returns to himself instead of providing it from the outside. They can not express their needs, feelings, and are associated with an intense sense of guilt and responsibility ${ }^{47}$. Especially, instead of expressing their emotions, they succeed in stopping these emotions by exhibiting their behaviors ${ }^{48}$. This can be likened to the compulsive behavior of an OCD patient. In the correlation analysis we conducted, there was a high level of correlation with obsessive thoughts, and significant low-level correlation with obsessional checking and obsessional impulse subdimensions. The obsessive thoughts sub-dimension has the features of disappearance, uncontrollability, guilt, embarrassment and incompleteness ${ }^{45}$. Retroflection contact style users cannot meet the needs directly, and it always leads to an unfulfillment of needs. In the style of an unhealthy retroflection contact, this style of contact turns into a habit, becoming chronic and unnoticeable ${ }^{46}$. Kepner (2014) underlines that those who are shy, bulky, nervous, mixed-minded individuals have negative feelings about themselves ${ }^{48}$ and have a high score on the "Retroflection" contact style ${ }^{46}$. In addition, Byrness (1975) associates personality traits such as showing depressive features and lack of activity, loneliness, and confusion in the mind with "Retroflection" contact style ${ }^{46}$. In addition, Kepner (2013) underlines the fact that "retroreflecting" individuals are very careful about being in control and fearful of the disappearance of this control they have developed 49 .

Table 2. Examination of the normality of the points that the Patient and Control Group receives from the scales: Shapiro-Wilk normality analysis

\begin{tabular}{|l|c|c|c|}
\hline \multirow{2}{*}{} & \multicolumn{2}{|c|}{ Shapiro-Wilk } \\
\cline { 2 - 4 } & Statistic & $n$ & $p$ \\
\hline Obsessive Thoughts & 0.922 & 100 & $0.000^{* *}$ \\
\hline Cleaning & 0.924 & 100 & $0.000^{* *}$ \\
\hline Impulses & 0.959 & 100 & $0.004^{*}$ \\
\hline Precision & 0.723 & 100 & $0.000^{* *}$ \\
\hline $\begin{array}{l}\text { Padua } \\
\text { Inventory }\end{array}$ & 0.714 & 100 & $0.000^{* *}$ \\
\hline Retroflection & 0.934 & 100 & $0.000^{* *}$ \\
\hline Deflection & & & $0.000^{* *}$ \\
\hline Contact & 0.930 & 100 & 0.166 \\
\hline Confluence & 0.981 & 100 & 0.282 \\
\hline Desensitisation & 0.984 & 100 & 0.147 \\
\hline
\end{tabular}

${ }^{*} p<0.01$. ${ }^{* *} p<0.001$.

Table 3. GCSS-RF: Deflection, Contact, Confluence and Desensitisation subscales average scores, standard deviations and t-test findings of Patient and Control Group

\begin{tabular}{|c|c|c|c|c|c|c|}
\hline \multicolumn{2}{|l|}{ Group } & $n$ & Avg & SD & $\mathrm{t}$ & $p$ \\
\hline \multirow[t]{2}{*}{ Deflection } & Patient & 50 & 40,44 & 7,71 & \multirow[t]{2}{*}{11,565} & \multirow[t]{2}{*}{$0.000^{* *}$} \\
\hline & Control & 50 & 24,22 & 6,24 & & \\
\hline \multirow[t]{2}{*}{ Contact } & Patient & 50 & 37,66 & 5,64 & \multirow[t]{2}{*}{$-3,745$} & \multirow[t]{2}{*}{$0.000^{* *}$} \\
\hline & Control & 50 & 41,84 & 5,52 & & \\
\hline \multirow[t]{2}{*}{ Confluence } & Patient & 50 & 46,12 & 5,11 & \multirow[t]{2}{*}{1,172} & \multirow[t]{2}{*}{0.244} \\
\hline & Control & 50 & 44,82 & 5,96 & & \\
\hline \multirow[t]{2}{*}{ Desensitisation } & Patient & 50 & 13,06 & 3,81 & \multirow[t]{2}{*}{$-3,299$} & \multirow[t]{2}{*}{$0.001^{*}$} \\
\hline & Control & 50 & 15,94 & 4,81 & & \\
\hline
\end{tabular}

${ }^{*} p<0.01 .{ }^{* *} p<0.001$.

Table 4. Patient and Control Group's Retroflection sub-dimension of GCSS-RF scale rank averages: Mann-Whitney analysis

\begin{tabular}{|l|c|c|c|c|c|}
\hline Group & $\mathrm{n}$ & Order Avg. & U & P \\
\hline Retroflection & Patient & 50 & 74,38 & \multirow{2}{*}{$0.000^{*}$} & \\
\cline { 2 - 6 } & Control & 50 & 26,62 & & \\
\end{tabular}


Table 5. Correlation analysis findings of scores of patients group on scales

\begin{tabular}{|c|c|c|c|c|c|c|}
\hline & & Retroflection & Deflection & Contact & Confluence & Desensitisation \\
\hline \multirow[t]{3}{*}{ Y-BOCS } & $r$ & 0.040 & 0.108 & 0.084 & 0.127 & 0.054 \\
\hline & $p$ & 0.783 & 0.454 & 0.560 & 0.378 & 0.707 \\
\hline & $n$ & 50 & 50 & 50 & 50 & 50 \\
\hline \multirow[t]{3}{*}{ Obsessive thoughts } & $r$ & 0.505 & 0.556 & -0.100 & 0.304 & -0.187 \\
\hline & $p$ & $0.000^{* * *}$ & $0.000^{* * * *}$ & 0.491 & $0.032^{*}$ & 0.193 \\
\hline & $n$ & 50 & 50 & 50 & 50 & 50 \\
\hline \multirow[t]{3}{*}{ Cleaning } & $r$ & -0.248 & -0.329 & 0.112 & 0.101 & -0.241 \\
\hline & $p$ & 0.082 & $0.020^{*}$ & 0.440 & 0.486 & 0.092 \\
\hline & $n$ & 50 & 50 & 50 & 50 & 50 \\
\hline \multirow[t]{3}{*}{ Control } & $r$ & 0.344 & 0.447 & -0.051 & 0.228 & -0.064 \\
\hline & $p$ & $0.015^{*}$ & $0.001^{* *}$ & 0.725 & 0.112 & 0.658 \\
\hline & $n$ & 50 & 50 & 50 & 50 & 50 \\
\hline \multirow[t]{3}{*}{ Impulses } & $r$ & 0.403 & 0.283 & -0.192 & 0.067 & -0.155 \\
\hline & $p$ & $0.004^{* *}$ & $0.047^{*}$ & 0.183 & 0.644 & 0.283 \\
\hline & $n$ & 50 & 50 & 50 & 50 & 50 \\
\hline \multirow[t]{3}{*}{ Precision } & $r$ & 0.183 & 0.248 & 0.068 & 0.209 & -0.085 \\
\hline & $p$ & 0.204 & 0.083 & 0.637 & 0.145 & 0.559 \\
\hline & $n$ & 50 & 50 & 50 & 50 & 50 \\
\hline \multirow[t]{3}{*}{ Padua inventory total score } & $\mathrm{r}$ & 0.294 & 0.294 & -0.020 & $0.293^{*}$ & -0.259 \\
\hline & $\mathrm{p}$ & $0.038^{*}$ & $0.038^{*}$ & 0.890 & $0.039^{*}$ & 0.069 \\
\hline & $\mathrm{n}$ & 50 & 50 & 50 & 50 & 50 \\
\hline
\end{tabular}

${ }^{*} p<0.05,{ }^{* *} p<0.01,{ }^{* * *} p<0.001$.

So they begin to compensate for the pressure created by emotions in other ways to control their own emotions. We can see such a loop in obsessive-compulsive symptoms seen in OCD individuals. The moral dilemmas suggest that one cannot make peace with himself, that he is alienated from himself, and that his relationship with this style of contact is meaningful.

In the "Deflection" contact style, it is seen that the patient group is using at a rather high level compared to the control group. It is the person's inability to see or hear these messages in order to reduce the number of messages that surround them, or to avoid the emotion that one might have caused by the effects of messages. Individuals who use the deflection contact style, does not pay attention to the person or situation to be contacted instead they tune in to something unrelated $^{28}$. Deflection, as the word implies, it explains blocking or directly avoiding contact ${ }^{50}$. The person keeps himself out of the real process and protects himself from the emotional-intellectual reactions that may occur. However, frequent use of deflection contact style will isolate the person from himself and his surroundings ${ }^{46}$. According to Chan et al. (2015), individuals who frequently use the deflection contact style weaken both their energy and focus on the wrong way of trying to get in touch. As a result, people can not get what they need to satisfy their needs ${ }^{51}$. Another common defensive mechanism in OCD is "reaction formation" 52,53 . Since showing real feelings will not be appropriate in the existing situation, counterreactions that show the emotions that are opposite to real emotions, but acceptable in that situation develops as a defense mechanism ${ }^{54}$. In the analysis of correlation we made, it was seen that the "Deflection" contact style had a high level of correlation with the obsessional thoughts and the checking, and a low level of correlation with the contamination and the impulses. Therefore, the defense mechanisms used by OCD patients also support the deflection contact style to be meaningful in the Patient Group.

"Contact" and "Emotional Desensitization" styles of contact are higher in the control group than in the patient group. These findings are consistent with the literature. There is more than one study that has a negative relationship between contact dimension and psychopathology $46,47,55$. When the elements of the contact dimension are examined, the elements contain elements for being in a social relationship and being content, forcing the boundaries to reach new things. An incompatible behavior occurs when we do not find a response at the time of personal need. Those who exhibit this behavior use the potential to manipulate others in order to do things they can not do for themselves (instead of making good contact) rather than timely responding to needs. This incompatible function exists with the loss of one's inner awareness and the absence of a good contact relationship ${ }^{56}$. The lack of a meaningful relationship between the "Emotional Desensitization" contact style and PI total score and subscales is consistent with the literature findings ${ }^{47,55}$. The active use of subscales of "Retroflection" and "Deflection" in particular and their high correlation with symptoms suggests that the "Emotional Desensitization" contact is not actively used.

When OCD individuals are evaluated in terms of Gestalt contact styles, it has been seen that the "retroflection" and "deflection" contact forms are intensively used, and in particular are intensively related to the subdimension of obsessional thoughts. OCD has been studied extensively in the literature and can cause considerable loss of capacity. Although studies are being done intensively, the treatment success does not exceed $50 \%$. In this sense, the evaluation of this disease with a new point of view, especially in the perspective of self-worth and moral dilemma, may increase the betterment of interventions for this disease. It helps both to better understand the disease and to provide alternatives to treatments that can yield a much better result in terms of treatment options.

Our study becomes more important as this is the first study in terms of the relationship between gestalt contact patterns and OCD symptoms. The low number of cases is a limitation in the evaluation of the data of the study. The inclusion of more people for future work may lead to a clearer understanding of the relationship. Analyzes made are correlations and T-test analyzes. But the evaluation of the mediating effect of symptoms may be considered for a better understanding of the effect of contact styles. Although age, sex, marital status and educational status of control group and patient group matched, variables such as temperament characteristics and duration of marriage could not be analyzed. In the following studies, it may be appropriate to include more detailed analysis considering both the drugs used, temperament characteristics and duration of marriage. 


\section{References}

1. Eisen JL, Mancebo MA, Pinto A, Coles ME, Pagano ME, Stout R, et al. Impact of obsessive-compulsive disorder on quality of life. Compr Psychiatry. 2006;47(4):270-5.

2. Norberg MM, Calamari JE, Cohen RJ, Riemann BC. Quality of life in obsessive-compulsive disorder: an evaluation of impairment and a preliminary analysis of the ameliorating effects of treatment. Depress Anxiety. 2008;25(3):248-59.

3. American Psychiatric Association (APA). Diagnostic and Statistical Manual of Mental Disorders (DSM-5 ${ }^{\circ}$ ). Philadelphia: APA; 2013.

4. Salkovskis PM. Obsessional-compulsive problems: a cognitive-behavioural analysis. Behav Res Ther. 1985;23(5):571-83.

5. Fisher PL, Wells A. How effective are cognitive and behavioral treatments for obsessive-compulsive disorder? A clinical significance analysis. Behav Res Ther. 2005;43(12):1543-58.

6. Foa EB, Liebowitz MR, Kozak MJ, Davies S, Campeas R, Franklin $\mathrm{ME}$, et al. Randomized, placebo-controlled trial of exposure and ritual prevention, clomipramine, and their combination in the treatment of obsessive-compulsive disorder. Am J Psychiatry. 2005;162(1):151-61.

7. Whittal ML, Thordarson DS, McLean PD. Treatment of obsessive-compulsive disorder: cognitive behavior therapy vs. exposure and response prevention. Behav Res Ther. 2005;43(12):1559-76.

8. Stanley MA, Turner SM. Current status of pharmacological and behavioral treatment of obsessive-compulsive disorder. Behav Ther. 1995;26:163-86.

9. Wetterneck CT, Hart JM. Intimacy is a transdiagnostic problem for cognitive behavior therapy: Functional Analytical Psychotherapy is a solution. Int J Behav Consult Ther. 2012;7:167.

10. Newth S, Rachman S. The concealment of obsessions. Behav Res Ther. 2001;39(4):457-64.

11. Rachman S. Obsessions, responsibility and guilt. Behav Res Ther. 1993;31(2):149-54.

12. Doron G, Kyrios M, Moulding R. Sensitive domains of self-concept in obsessive-compulsive disorder (OCD): further evidence for a multidimensional model of OCD. J Anxiety Disord. 2007;21(3):433-44.

13. Shafran R, Watkins E, Charman T. Guilt in obsessive-compulsive disorder. J Anxiety Disord. 1996;10(6):509-16.

14. Shapiro LJ, Stewart ES. Pathological guilt: a persistent yet overlooked treatment factor in obsessive-compulsive disorder. Ann Clin Psychiatry. 2011;23(1):63-70.

15. Tallis F. Obsessions, responsibility and guilt: two case reports suggesting a common and specific aetiology. Behav Res Ther. 1994;32(1):143-5.

16. Mancini F, D’Olimpio F, Cieri L. Manipulation of responsibility in non-clinical subjects: does expectation of failure exacerbate obsessive-compulsive behaviors? Behav Res Ther. 2004;42(4):449-57.

17. Doron G, Moulding R, Kyrios M, Nedeljkovic M. Sensitivity of self-beliefs in obsessive compulsive disorder. Depress Anxiety. 2008;25(10):874-84.

18. Zhong C-B, Liljenquist $\mathrm{K}$. Washing away your sins: threatened morality and physical cleansing. Science. 2006;313(5792):1451-2.

19. Reuven O, Liberman N, Dar R. The effect of physical cleaning on threatened morality in individuals with obsessive-compulsive disorder. Clin Psychol Sci. 2014;2:224-9.

20. Fergus TA, Valentiner DP, McGrath PB, Jencius S. Shame- and guilt-proneness: relationships with anxiety disorder symptoms in a clinical sample. J Anxiety Disord. 2010;24(8):811-5.

21. Rachman S. Unwanted intrusive images in obsessive compulsive disorders. J Behav Ther Exp Psychiatry. 2007;38(4):402-10.

22. Tangney JP, Wagner P, Gramzow R. Proneness to shame, proneness to guilt, and psychopathology. Erratum: Journal of Abnormal Psychology 1992 Nov;101(4):738. J Abnorm Psychol. 1992;101(3):738-8.

23. Kabat-Zinn J. Mindfulness-based interventions in context: Past, present, and future. Clinical Psychology: Science and Practice. 2003;10:144-56.

24. Gaines J, Perls FS. Fritz Perls: Here and now. Millbrae, CA; 1979.

25. Akkoyun F. Gestalt terapi. Ankara: Nobel Yayın Dağım; 2001. p. 85-9.

26. Joyce P, Sills C. Skills in Gestalt Counselling \& Psychotherapy. London: SAGE; 2001

27. Latner J. This is the speed of light: field and systems theories in Gestalt therapy. Gestalt J. 1983;6:1-20.

28. Houston G. Brief Gestalt Therapy. SAGE; 2003.
29. Lee RG, Wheeler G. Self and shame: A new paradigm for psychotherapy The Voice of Shame: Silence and Connection in Psychotherapy. San Francisco: Jossey Bass. 1996. p. 48.

30. van Baalen D. Gestalt Therapy and Bipolar Disorder. Gestalt Rev 2010;14:71-88

31. Seligman LW, Reichenberg LW. Theories of Counseling and Psychotherapy: Systems, Strategies, and Skills MyLab Counseling Without Pearson eText - Access Card Package. London: Pearson Education; 2015.

32. Ellison JA, Greenberg LS, Goldman RN, Angus L. Maintenance of gains following experiential therapies for depression. J Consult Clin Psychol. 2009;77(1):103-12.

33. Williams L. Making contact with the self-injurious adolescent: Borderline personality disorder, Gestalt therapy, and dialectical behavioral therapy interventions. Gestalt Rev. 2010;14:250-74.

34. Sharf RS. Theories of Psychotherapy \& Counseling: Concepts and Cases. Boston, MA: Cengage Learning; 2015.

35. Pfluger I. Gestalt approaches to working with clients presenting with bulimia. Gestalt Journal of Australia and New Zealand. 2014;10:60.

36. Arnfred SMH. Gestalt therapy for patients with schizophrenia: A brief review. Gestalt Rev. 2012;16:53.

37. Siampani K. Incorporating sandplay therapy into gestalt therapy in the treatment of dementia. Gestalt Rev. 2013;17:35.

38. Yorgun A, Voltan-Acar N. The Practicality of Reality Therapy in Turkish Culture: An Analytical Overview. Eğitim ve Bilim. 2014;39(175).

39. Voltan-Acar N. Ne kadar farkındayım?: Gestalt terapi. Babil Yayıncılık; 2004.

40. Goodman WK, Price LH, Rasmussen SA, Mazure C, Fleischmann RL, Hill CL, et al. The Yale-Brown Obsessive Compulsive Scale. I. Development, use, and reliability. Arch Gen Psychiatry. 1989;46(11):1006-11.

41. Goodman WK, Price LH, Rasmussen SA, Mazure C, Delgado P, Heninger GR, et al. The Yale-Brown Obsessive Compulsive Scale. II. Validity. Arch Gen Psychiatry. 1989;46(11):1012-6.

42. Karamustafalığlu KO, Ücısık AM, Ulusoy M, Erkmen H. Yale-Brown obsesyon-kompulsiyon derecelendirme ölçeğinnin geçerlilik ve güvenilirlik çalışması. Savaş Ofset. 1993:33.

43. Sanavio E. Obsessions and compulsions: the Padua Inventory. Behav Res Ther. 1988;26(2):169-77.

44. van Oppen P. Obsessions and compulsions: dimensional structure, reliability, convergent and divergent validity of the Padua Inventory. Behav Res Ther. 1992;30(6):631-7.

45. Beşiroğlu L, Ağargün MY, Boysan M, Eryonucu B, Gulec M, Selvi Y Obsesif-kompulsif belirtilerin değerlendirilmesi: Padua Envanteri’nin Türk toplumunda geçerlik ve güvenilirliği. Türk Psikiyatri Dergisi. 2005;16:179-89.

46. Aktaş CG, Daş C. Geştalt Temas Biçimleri Yeniden Düzenlenmiş Formunun Türk örnekleminde faktör yapısı, geçerliliği ve güvenirliği. Temas Gestalt Terapi Dergisi. 2002;1:83-110.

47. Kudiaki Ç, Sezgin N. An examination of Gestalt contact styles, anger and anxiety levels of headache and non headache groups (Turkish). J Clin Psychiatry. 2018;21:68-78.

48. Kepner JI. Body process: A gestalt approach to working with the body in psychotherapy. Santa Cruz, CA: Gestalt Press; 2014.

49. Kepner JI. Healing tasks: Psychotherapy with adult survivors of childhood abuse. New York: Gestalt Press; 2013.

50. Mann D. Gestalt Therapy: 100 Key Points and Techniques. Abingdon: Routledge; 2010.

51. Chan F, Berven NL, Thomas KR. Counseling Theories and Techniques for Rehabilitation and Mental Health Professionals. 2nd ed. New York, NY: Springer Publishing Company; 2015.

52. Gabbard GO. Psychoanalytically informed approaches to the treatment of obsessive-compulsive disorder. Psychoanalytic Inquiry. 2001;21:208-21.

53. Pollock C, Andrews G. Defense styles associated with specific anxiety disorders. Am J Psychiatry. 1989;146(11):1500-2.

54. Cüceloğlu D. İnsan ve davranışı. Remzi Kitabevi; 2015.

55. Balkaya F, Tuğrul C. Üniversite öğrencilerinde temas biçimlerinin öfke ve anksiyete ile ilişkisi. Yayınlanmamış Doktora Tezi Ankara Üniversitesi, Sosyal Bilimler Enstitüsü, Ankara; 2006.

56. Jones-Smith E. Theories of Counseling and Psychotherapy: An Integrative Approach. London: SAGE Publications; 2011. 